\title{
Mobilitas Sosial Pada Kelompok Zainichi Korean Di Jepang
}

\author{
Ni Putu Luhur Wedayanti ${ }^{1)}$, Ni Made Andry Anita Dewi ${ }^{2)}$ \\ Program Studi Sastra Jepang, Fakultas Ilmu Budaya \\ Universitas Udayana, Denpasar Bali \\ Email: luhur_wedayanti@unud.ac.id \\ andry_anita@unud.ac.id
}

\begin{abstract}
Abstrak
Penelitian ini mengkaji mengenai faktor yang mendukung terjadinya mobilitas, maupun faktor yang menghambat serta bentuk mobilitas yang terjadi pada kelompok minoritas Zainichi Korean di Jepang. Zainichi Korean merupakan masyarakat imigran yang datang ke Jepang sebagai tenaga kerja informal pada tahun 1910 saat Korea menjadi daerah koloni Jepang. Para imigran Korea yang datang pada saat itu, merupakan generasi pertama. Zainichi Korean generasi pertama yang tidak kembali ke negaranya, menetap di Jepang sampai saat ini hingga generasi keempat atau kelima. Beberapa dekade lalu, diskriminasi terhadap para imigran Korea menyulitkan mereka untuk mendapatkan penghidupan yang layak, karena mereka kesulitan untuk mencari pekerjaan. Mereka hanya bisa bekerja sebagai pekerja harian. Akan tetapi, karena berbagai faktor pendukung misalnya kesempatan dan kerja sama yang baik, sebagian besar para imigran Korea ini mampu memiliki bisnis Pachinko, bahkan hampir menguasai bisnis toko perhiasan di Osaka sebagai sentra pemukiman imigran Korea paling banyak di Jepang. Perubahan tersebut, menunjukkan adanya mobilitas sosial para imigran Korea ke kelas sosial ekonomi yang lebih tinggi. Di lain pihak, faktor yang menghambat terjadinya mobilitas adalah adanya sikap diskriminatif dari penduduk asli.
\end{abstract}

Kata kunci: mobilitas sosial, zainichi Korean.

\begin{abstract}
This study has a purpose to examine wether any social mobility occurred within Zainichi Korean in Japan. Zainichi Korean is a minority group that came to Japan since 1910 when Korean Peninsula was annexed by Japanese. Korean who came to Japan that time worked as daily worker in farming area, ship building, contruction site or other places. After World War II was ended, part of those Korean stayed remain in Japan, until this moment for fourth or fifth generatons. Decades ago, discrimination against Korean immigrants made it difficult for them to earn a decent living, as they struggled to find a decent work. They could only work as day laborers. However, due to various supporting factors such as opportunities and good cooperation, most of these Korean immigrants were able to own a Pachinko business, and even almost controlled the jewelry shop business in Osaka as the center of a settlement of the most Korean immigrants in Japan. This change shows the social mobility of Korean immigrants to a higher socioeconomic class. On the other hand, the factor that hinders the occurrence of mobility is the discriminatory attitude towards Zainichi Korean.
\end{abstract}

Keywords: social mobility, Zainichi Korean.

\section{Pendahuluan}

Pelapisan masyarakat menjadi kelas-kelas tertentu secara vertikal maupun perbedaan horisontal merupakan fenomena alami yang terjadi di sebagian besar masyarakat di dunia. 
Secara natural manusia senantiasa mengelompokkan dirinya berdasarkan beberapa kesamaan dan meliyankan (othering) kelompok lain yang berbeda dengannya. Pengelompokkan maupun pelapisan dalam masyarakat ini ada yang terbentuk secara alami, tetapi tidak jarang juga dilakukan secara sengaja oleh pihak yang mendapat keuntungan dengan terbelahnya masyarakat. Misalnya, pada masa penjajahan Belanda di Indonesia. Masyarakat di Bali dibagi menjadi empat kelas yang sifatnya tertutup berdasarkan garis keturunan oleh Belanda dengan mengadaptasi sistem kasta di India. Penggolongan masyarakat berdasarkan profesi dan fungsi diadaptasi dari India bersamaan dengan datangnya agama Hindu. Akan tetapi, sejak penjajahan Belanda konsep catur varna dan kasta menjadi kabur (Damayanti, 2020). Masyarakat yang telah terkotak-kotakkan, memudahkan Belanda sebagai penjajah saat itu dalam mengatur maupun mengawasi pergerakan masyarakat koloninya. Hal tersebut sejalan dengan yang disampaikan oleh Davis dan Moore (Soyomukti, 2014) bahwa stratifikasi sosial berfungsi menjelaskan posisi seseorang dalam masyarakat.

Jepang juga merupakan negara yang secara historis memiliki jejak membagi masyarakatnya dalam beberapa kelas berdasarkan pekerjaan yang dilakukan dari generasi ke generasi. Pada jaman pemerintahan Edo, masyarakat Jepang saat itu dibagi menjadi empat kelas utama yaitu, kelompok samurai, petani, tukang atau pekerja, dan pedagang, yang disebut shinokoso. Di luar kelas shinokoso, ada kelas yang lebih tinggi yang disebut kuge (kelas bangsawan) dan buke (kelas para shogun dan daimyo) (Suherman, 2004). Tersisih dari semua kelas, ada juga kelompok masyarakat yang dianggap sangat rendah, bahkan tidak dimasukkan ke dalam kelas kelompok masyarakat saat itu (shinokoso) yaitu kelompok masyarakat buraku.

Pelapisan masyarakat berdasar pada profesi ini, menempatkan burakumin pada posisi bawah, yang bahkan lebih di bawah dan tidak termasuk dalam kelas shinokoso. Mereka disisihkan karena pekerjaan yang mereka lakukan secara turun temurun dianggap pekerjaan yang kotor dan nista. Sehingga kelompok ini selalu terpinggirkan dan dianggap mengotori lingkungannya. Setelah runtuhnya Bakufu, sistem stratifikasi sosial masyarakat, ataupun keberadaan kelas lainnya dihapuskan. Meskipun penghapusan kelas sosial telah dilakukan, tetapi, eksklusivitas antar golongan yang tidak terlihat tetap eksis dalam masyarakat Jepang. Kelas shinokoso telah dihapuskan dan bertransformasi menjadi stratifikasi ataupun diferensiasi sosial bentuk lain. Dalam hal ini, kelompok Zainichi Korean 
berada pada lapisan lebih rendah dari masyarakat umumnya. Hal tersebut karena alasan historis mereka datang pertama kali ke Jepang sebagai tenaga yang murah dan bekerja di sektor informal. Setelah perang, akses pendidikan ataupun pekerjaan bagi mereka lebih sulit digapai, otomatis pada masa-masa tersebut kelompok ini tidak berada pada hirarki yang tinggi atau setidaknya menengah ke atas di masyarakat Jepang. Artikel ini membahas mengenai mobilitas sosial yang terjadi pada kelompok minoritas di Jepang, yaitu kelompok Zainichi Korea. Konsep mengenai mobilitas sosial digunakan untuk menjelaskan mobilisasi yang terjadi dalam kelompok imigran Korea yang menetap di Jepang.

\section{Metode dan Teori}

\subsection{Metode Penelitian}

Penelitian ini merupakan penelitian kualitatif yang merupakan penelitian untuk memahami ataupun mengeksplorasi makna dari tingkah laku suatu komunitas atau masyarakat. Dalam hal ini, peneliti kualitatif berusaha membangun makna tentang suatu fenomena yang terjadi di masyarakat berdasarkan pada pandangan pengalam (Creswell, 2014). Pendekatan metode penelitian kualitatif sangat bertujuan memahami interaksi individu dalam komunitas tempatnya tinggal. Prosedur pengumpulan data yang dilakukan dengan prosedur dokumentasi. Peneliti mengumpulkan dokumen publik seperti makalah, hasil penelitian mengenai zainichi Korea. Sumber data tertulis yang didapatkan tersebut, memberikan kajian yang mendalam terkait objek penelitian ini, sehingga sangat membantu dalam proses analisis data. Konsep mengenai mobilitas sosial digunakan untuk mengenali fenomena mobilitas yang terjadi pada kelompok minoritas yang telah disebutkan, dan penyajian hasil analisis menggunakan metode informal dengan dekspripsi berupa narasi yang jelas terkait hasil analisis.

\subsection{Teori}

Teori yang digunakan dalam penelitian ini adalah teori mobilisasi Sosial. Hal ini terkait dengan stratifikasi sosial merupakan hal yang wajar terjadi di masyarakat. Masyarakat dengan sendirinya memberikan label ataupun posisi lebih tinggi bagi kelompok yang memiliki harta lebih banyak, pencapaian yang lebih tinggi (yang berujung pada peningkatan taraf hidup secara ekonomi), ataupun parameter lainnya. Dan, mem- 
berikan penilaian yang lebih rendah bagi kalangan yang tidak memiliki sesuatu yang berharga dalam pandangan masyarakat tersebut. Sorokin mengatakan bahwa stratifikasi sosial adalah pembedaan penduduk atau masyarakat ke dalam kelas-kelas secara bertingkat. Sementara Weber mendefinisikan strata sosial sebagai penggolongan orang-orang yang termasuk ke dalam suatu sistem sosial tertentu sesuai lapisan hierarki menurut dimensi kekuasaan, previlese, dan prestise. Mobilitas sosial dipengaruhi oleh faktor kontak sosial dan komunikasi (interaksi sosial). Dalam interaksi sosial yang tertutup (batas-batas pergaulan antara minoritas kelas atas dan mayoritas kelas bawah yang tebal), pergaulan yang eksklusif, kemungkinan terjadinya mobilitas sosial sangat sulit (dalam Soyomukti, 2014). Kajian terkait stratifikasi sosial, mobilitas sosial telah banyak dikaji oleh peneliti lain (Fanani, 2017; Nasiwan \& Wahyuni, 2016; Wirawan, 2015). Adapun Soyomukti (2014) menyampaikan beberapa faktor penghalang terjadinya mobilitas sosial, diantaranya :

a) Rasialisme, yaitu perasaan/pandangan bahwa ras yang dianggap rendah tidak boleh menduduki tempat-tempat atau posisi-posisi sebagai mana ras lainnya.

b) Agama, seperti yang terjadi pada agama-agama yang mendukung sistem kasta, misalnya di India.

c) Kemiskinan yaitu suatu kondisi yang membuatnya tidak memiliki modal untuk membiayai diri mendapatkan pendidikan (pengetahuan dan keterampilan) sehingga ia tak akan bisa mendapatkan pekerjaan yang lebih baik.

d) Perbedaan jenis kelamin, yaitu pandangan yang menganggap bahwa suatu kedudukan atau pekerjaan hanya pantas dilakukan oleh jenis kelamin tertentu.

e) Budaya Kolusi dan Nepotisme, yaitu budaya memberikan jabatan dan kedudukan pada anggota keluarga, kerabat dan saudara, atau orang-orang yang memberinya sogokan.

Mobilitas sosial itu sendiri didefinisikan sebagai proses perpindahan dari kedudukan satu ke kedudukan lainnya yang lebih tinggi atau sebaliknya. Young dan Mack mendefinisikan mobilitas sosial sebagai suatu gerak dalam struktur yaitu pola-pola tertentu yang mengatur organisasi suatu kelompok sosial. Struktur sosial mencakup sifat hubungan antara individu dalam kelompok serta hubungan antara individu dan kelompoknya. Dalam pengertian sosiologi secara umum, mobilitas sosial didefinisikan sebagai perubahan status sosial atau status pekerjaan seseorang. Giddens merujuk mobilitas sosial sebagai proses dimana para individu berpindah dari satu posisi ke posisi lainnya dalam suatu 
komunitas atau masyarakat (Pattinasarany, 2012). Menyangkut perpindahan kelas, dari kelas asal orang tua (class origin) ke kelas yang dituju (class destination) perlu ditegaskan bahwa komunitas Zainichi Korean ini berada pada kelas yang lebih rendah secara sosial ekonomi pada masa awal kedatangan mereka. Karena sebagian besar mereka datang untuk mengisi kekurangan tenaga kerja sektor informal di Jepang.

\section{Kajian Pustaka}

Penelitian Arifin menulis mengenai Korelasi Pendidikan Tinggi dan Mobilitas Sosial di Indonesia. Menurut Burlutskaia perguruan tinggi menjadi sarana mobilitas sosial vertikal bagi masyarakat dan secara khusus membuka pintu kelas sosial menengah bagi masyarakat lapisan bawah. Beberapa studi empiris ditunjukkan dalam artikel ini mengenai korelasi yang positif antara jenjang pendidikan dan tingkat pendapatan seseorang. Hubungan positif tingkat pendidikan dengan mobilitas sosial dibuktikan juga oleh Pattinasarany (Arifin, 2017), bahwa semakin tinggi tingkat pendidikan, semakin besar kemungkinan terjadinya mobilitas sosial ke atas (upward mobility).

Terdapat ketimpangan dalam akses masuk perguruan tinggi yang disebabkan beberapa faktor, diantaranya, latar belakang status sosial ekonomi, dan disparitas geografi dan kultural. Siswa yang hidup dalam rumah tangga dengan status sosial yang rendah, disebutkan memiliki peluang yang lebih rendah untuk masuk perguruan tinggi. Meskipun pemerintah Indonesia telah memprogramkan beasiswa BIDIK MISI dengan jumlah siswa diterima meningkat seiring tahun, akan tetapi menurut Logli (Arifin, 2017) jumlah yang terjaring beasiswa tersebut masih relatif kecil dibandingkan dengan proporsi calon mahasiswa potensial yang tidak memiliki akses ke perguruan tinggi karena biaya. Selain itu juga, beberapa lembaga pemberi beasiswa hanya menyediakan biaya kuliah, sehingga siswa dari keluarga yang kesulitan secara ekonomi harus berpikir ulang untuk melanjutkan kuliah mengingat biaya diluar biaya pendidikan juga tidak bisa diabaikan. Disparitas geografi oleh Moeliodihardjo (Arifin, 2017) didefinisikan sebagai kondisi tidak tersedianya infrastruktur sosial dan ekonomi di wilayah-wilayah tertinggal dan umumnya terpencil. Sedangkan disparitas kultural menggambarkan tingkat aksesibilitas dalam hal ini ke perguruan tinggi sangat dipengaruhi oleh aspek suku, bahasa dan gender.

Penelitian yang dilakukan oleh Arifin (Arifin, 2017) menjadi referensi yang memberikan pemahaman mengenai mobilitas sosial yang terjadi di masyarakat. Dan korelasi 
dengan penelitian ini sangat erat, karena masyarat yang terjebak dalam suatu kelas sosial pun memiliki harapan untuk bermobilisasi ke atas jika memiliki tingkat pendidikan yang lebih tinggi. Hal ini juga terjadi pada kelompok minoritas di Jepang, misalnya para Zainichi Korean yang mampu mengenyam pendidikan tinggi memiliki peluang untuk bekerja dalam bidang yang lebih variatif dengan upah yang lebih layak.

Wahyuningtyas meneliti mengenai mobilitas imigran Cina di Indonesia. Studi terkait mobilitas yang terjadi pada beberapa kasus di masyarakat disampaikan dalam penelitian ini. Alexandru dan Inglish (Wahyuningtyas, 2017) membuktikan adanya dampak positif dengan terjadinya mobilitas individu. Sebagian besar daerah tempat tujuan migrasi adalah negara-negara yang memiliki kemapanan sistem pendidikan, kesehatan, ataupun aspek lainnya dalam kehidupan yang lebih baik dari daerah asalnya. Berbagai kajian pustaka yang dilakukan mengacu pada pentingnya faktor pendidikan, latar belakang keluarga, social capital dalam upaya menentukan mobilitas sosial. Pada sebagian besar komunitas, pendidikan menjadi investasi yang bermanfaat karena mampu mengantarkan individu ataupun kelompok sosial pada kelas yang lebih tinggi. Karena dengan pendidikan yang dilakukan serius, terjadi perubahan pola pikir dan pergaulan sosial.

Hanya saja, Wahyuningtyas menemukan bahwa pendidikan berdampak minimal dalam mendorong terjadinya mobilitas sosial pada etnis keturunan Tionghoa di Indonesia. Mobilitas imigran mengalami mobilitas naik sebesar $82 \%$ dengan mayoritas kenaikan berasal dari kategori kelas menengah. Kemudian, terdapat perbedaan tingkat mobilitas apabila dipisahkan antara pendapatan dan okupasi. Pada tingkat okupasi, mobilitas yang ditunjukkan cenderung stagnan dengan persentase $60 \%$ dan berasal dari kategori kelas menengah. Sedangkan, pada pendapatan mobilitas naik terjadi sangat signifikan sebesar 84\% dengan proporsi pergerakan lebih banyak dari kelas menengah ke kelas atas.

Sesuai dengan yang telah disampaikan, hubungan antara tingkat pendidikan dan peluang mobilitas cenderung rendah. Faktor jaringan, peluang di sektor informal, dan budaya kerja dengan disiplin yang tinggi menjadi akses yang memudahkan para keturunan Tionghoa untuk merintis bisnis di Indonesia. Sektor informal yang diharapkan mampu menyerap tenaga kerja lokal, memiliki sumber daya manusia lokal yang cenderung rendah, menjadi peluang untuk bergabung dan memulai bisnis antara sesama imigran. Kesempatan untuk bersaing dengan persaingan yang rendah juga menjadi kesempatan emas untuk memulai melakukan mobilitas. Dengan bergabung dan memulai dari sektor informal, 
imigran akan mendapatkan tempat yang aman dan jauh dari resiko resesi ekonomi, seperti pembayaran pajak investasi asing, upah yang rendah, dan hal lainnya terkait aturan tenaga kerja asing yang terlalu formal. Satu-satunya hal yang dianggap rentan adalah kemungkinan terjerat hukum penggelapan dan hukuman deportasi ke negara asal (Wahyuningtyas, 2017).

\section{Hasil dan Pembahasan}

Penelitian ini berfokus pada fenomena mobilitas sosial yang terjadi pada kelompok minoritas Zainichi Korean di Jepang. Pembahasan dibagi menjadi tiga bagian, dengan bagian awal menjelaskan terkait istilah Zainichi Korean, dilanjutkan dengan kajian historis keberadaan Zainichi Korean, serta bentuk-bentuk mobilitas sosial yang terjadi dalam kelompok ini.

\subsection{Definisi Zainichi Korea di Jepang}

Secara etimologis, istilah zainichi yang berasal dari huruf kanji 在zai 'tinggal; berada' dan nichi 日 yang berarti 'hari; hari Minggu; Jepang'. Dalam konteks istilah ini arti yang digunakan adalah 'Jepang' untuk mendefinisikan orang yang tinggal di Jepang. Kata 在日 zainichi ‘imigran’ dapat diartikan sebagai 日本に存在する人Nihon ni sonzai suru hito 'orang yang berada di Jepang'. Sehingga dua kata ini dapat dimaknai sebagai 'orang yang saat ini sedang tinggal atau menetap di Jepang'. Melihat dari arti katanya, kata zainichi bermakna cukup netral, dan digunakan untuk warna negara asing yang tinggal di Jepang. Misalnya untuk menyebut imigran asal Indonesia yang sedang tinggal di Jepang dengan zainichi Indonesiajin 'orang Indonesia yang tinggal/berada di Jepang (imigran dari Indonesia)' (Wedayanti, 2021)

Pada perkembangannya, kata zainichi ini lebih identik digunakan untuk menyebut para imigran Korea yang telah tinggal menetap di Jepang selama beberapa generasi. Cukup banyak Zainichi Korea yang telah menjalani naturalisasi dan menjadi warga negara Jepang, tetap menyebut diri mereka adalah warga negara Jepang dengan tanah leluhur Korea (Wedayanti, 2021). Meskipun dalam proses naturalisasi, mereka harus menggunakan nama lazimnya orang Jepang, tetapi para Zainichi Korean ini di situasi informal beberapa masih memiliki nama keluarga Korea. 


\subsection{Keberadaan Zainichi Korea di Jepang}

Isu mengenai masyarakat Jepang yang mengklaim dirinya sebagai masyarakat homogen dengan kelas sosial menengah, telah dipertanyakan oleh para peneliti dan pemerhati sosial dari tahun ke tahun (Brown, 2013; Burgess, 2005; Lie, 2004; Sugimoto, 2010). Menurut Sugimoto, di areal industri di Jepang, wajah-wajah asing telah memenuhi kota bersamaan dengan papan reklame ataupun penunjuk lalu lintas yang tidak hanya berbahasa Jepang untuk mengakomodasi kebutuhan para imigran yang tidak bisa berbahasa Jepang. Di daerah pedesaan Jepang pun, terdapat banyak imigran wanita yang menikah dengan pria petani Jepang karena wanita Jepang pada umumnya enggan untuk hidup sebagai petani di pedesaan. Sugimoto juga menyebutkan bahwa para imigran, seperti keturuan Jepang Brasil, keturunan Korea Jepang, Suku Ainu ataupun burakumin sebagai kelompok minoritas di Jepang (Brown, 2013; Wedayanti, 2021). Dengan bukti tersebut, pemikiran ataupun pemahaman Jepang negara yang unik dengan monoras ataupun monolingual perlu dikaji dengan lebih kritis, terutama pada masa globalisasi saat ini.

Setelah menjadi koloni Jepang pada tahun 1910, kurang lebih sekitar 2,3 juta orang Korea masuk ke Jepang untuk menjadi tenaga kerja murah di bidang pertambangan, konstruksi ataupun perakitan kapal. Banyak warga Korea yang dibawa paksa untuk bekerja di Jepang, untuk mengatasi kekurangan tenaga kerja di Jepang. Setelah perang dunia kedua, selama rentang waktu enam bulan, sebanyak 1,7 juta orang Korea kembali ke negaranya, sedangkan sisanya memilih untuk tinggal di Jepang (Sugimoto, 2010). Hal tersebut karena mereka merasa tidak memiliki apapun yang tersisa di Korea setelah ditinggal ke Jepang dalam waktu yang lama, dan merasa akan sulit untuk hidup di Korea.

Setelah perang, Semenanjung Korea dibagi menjadi Korea Utara dan Korea Selatan. Pembagian tersebut berpengaruh juga pada Zainichi Korea yang tinggal di Jepang. Mereka menunjukkan loyalitasnya kepada negara asal mereka dengan membentuk kelompok sesuai dengan preferensi politisnya. Terdapat dua kelompok warga Korea di Jepang, yaitu Mindan (Perkumpulan Warga Korea yang berorientasi ke Korea Selatan) dan Chongryun yang berorientasi ke Korea Utara. Kedua kelompok ini menunjukkan ekskulisivitasnya, terutama dalam hal penanaman nilai-nilai budaya pada generasi mudanya. Kebanyakan keturunan dari kelompok Chongryun di sekolahkan pada sekolah khusus dengan sistem pendidikan mengikuti Korea Utara. 
Sejak kedatangan para imigran Korea ke Jepang pertama kali hingga dewasa ini, kemungkinan telah lima generasi menetap di Korea. Dalam perkembangannya, lahir gap yang sangat jelas mengenai pandangan antar generasi ini terkait status dan identitasnya sebagai imigran Korea yang tinggal di Jepang. Para generasi pertama tetap mempertahankan loyalitas mereka terhadap tanah kelahiran dan pemerintah di negara asalnya. Sedangkan, generasi kedua dan ketiga yang lahir dan besar di Jepang, memiliki pemikiran yang berbeda dan memiliki minat yang lebih sedikit dibandingkan generasi sebelumnya terkait tanah leluhurnya. Tetapi mereka masih menjadi generasi yang berada pada masa transisi dan berada di tengah-tengah antara jati diri sebagai orang Korea dan hidup seperti orang Jepang. Sebagian besar dari mereka mempelajari bahasa Korea sebagai bahasa kedua, dan memiliki hanya sedikit pengetahuan terkait sejarah maupun kultur Korea, tetapi menikmati budaya Jepang selayaknya anak-anak muda Jepang. Generasi yang bahkan lebih muda, menginginkan hidup layaknya sebagai warga negara Jepang dengan hak dan kewajiban yang sama (Sugimoto, 2010).

Fukuoka mengindetifikasi generasi muda Korea di Jepang menjadi empat tipe (Sugimoto, 2010), yaitu :

Tipe A : Tipe ini adalah tipe yang sangat loyal kepada tanah asal nenek moyangnya dan merasa diri mereka sebagai korban dari kolonialisasi Jepang, dan menolak segala bentuk asimilasi dengan orang Jepang. Banyak orang Korea tipe ini biasanya adalah bilingual, karena mereka mempertahankan identitas mereka sebagai orang Korea. Tipe ini umumnya termasuk ke dalam kelompok Chongryun.

Tipe B : Tipe ini lebih bersikap individualistis, mereka tidak terlalu memberikan perhatian kepada konflik masa lalu, tidak juga terlalu terlibat dengan kehidupan masyarakat Jepang. Mereka orang yang berorientasi bisa meningkatkan kapasitas mereka secara individu tanpa banyak bersandar pada kelompok.

Tipe C : Tipe ini lebih mirip dengan Tipe A yang memiliki kepedulian terkait identitas mereka sebagai orang Korea. Akan tetapi, tidak menutup diri seperti Tipe A, generasi muda Korea tipe C menyadari situasi mereka yang lahir dan hidup di negara Jepang. Sehingga mereka memiliki gaya hidup yang multikultur. Sebagian besar dari mereka juga bersekolah di 
sekolah Jepang dan bahasa pertamanya adalah bahasa Jepang. Mereka mulai tertarik dan mendalami bahasa ataupun budaya nenek moyangnya, ketika terlibat dan menyadari adanya isu rasisme yang menyerah kelompoknya.

Tipe D : Tipe ini adalah tipe yang menerima asimilasi sepenuhnya, dan menjalani gaya hidup dan pola pikir yang hampir sama seperti anak muda Jepang pada umumnya.

\subsection{Mobilitas Sosial Zainichi Korean di Jepang}

Zainichi Korean merupakan kelompok minoritas yang memiliki sejarah panjang perlakuan diskriminatif di Jepang. Setelah beberapa generasi, kemiripan fisiologis antara masyarakat Jepang dan Korea, membuat proses asimilasi imigran Korea di Jepang dapat dikatakan hampir sempurna (Kim, 2011). Generasi ketiga imigran Korea hampir sulit dibedakan atau dikenali jejak kekoreaannya karena mereka dapat berbahasa Jepang dengan baik, berpakaian seperti orang Jepang, bahkan orang Jepang sendiri sering salah menebak identitas mereka. Dengan fakta seperti itupun sebagian orang Jepang masih sulit untuk menerima imigran Korea, tanpa mempertimbangkan latar belakangnya(Harun, 2016).

Para Zainichi Korean ini pada mulanya adalah mereka yang bekerja hanya di sektor nonformal. Atau pekerjaan yang lebih dikenal dengan 3K yaitu kiken, kitanai, kitsui, atau dalam bahasa Indonesia berarti 'berbahaya, kotor, berat/keras' secara berurutan, yang umumnya enggan untuk dikerjakan oleh orang Jepang (Wedayanti \& Dewi, 2021). Setelah generasi kedua dan ketiga, perekonomian Zainichi Korean ini pun meningkat, bahkan saat ini hampir 70\% pengusaha perhiasan di Jepang adalah zainichi korea ini, di kota seperti Osaka yang memiliki imigran Korea paling besar di Jepang (Burgess, 2005). Pemilik Pachinko di Jepang, sekitar 60-70\% dikatakan bahwa dimiliki oleh orang keturuna Korea (Zainichi Korean). Seperti yang telah disampaikan bahwa orang Korea kesulitan untuk mencari pekerjaan, dan hanya diterima sebagai pekerja harian pada restoran yakiniku, ataupun pada tempat-tempat pachinko.

Pada tahun 1960an, para Zainichi Korean masih menjadi objek penekanan oleh pihakpihak tertentu di masyarakat. Akses pada dunia pendidikan, ataupun pergaulan yang sifatnya terbuka dengan semua kalangan masih terbatas. Masyarakat Jepang juga mengenal 
konsep dikotomi uchi-soto yang mengelompokkan seseorang di dalam kelompoknya (ingroup) atau di luar kelompoknya (out-group) yang teraplikasi dinamis tergantung lingkup pergaulan. Terutama pada akses untuk mendapatkan pekerjaan yang diinginkan. Beberapa artis ataupun olahragawan harus menyembunyikan kenyataan mereka adalah keturunan Korea untuk dapat berkarir di ranah profesi tersebut. Misalnya pesumo Rikidozan yang pergi ke Amerika untuk menjadi pegulat saat berada di puncak karirnya pada tahun 1950. Rikidozan menyampaikan bahwa pengunduran dirinya dari dunia Sumo dan pergi ke Amerika karena motif finansial, tetapi menurut Ushijima kemungkinan adanya diskriminasi karena dia keturunan Korea bisa menjadi salah satu faktor keputusannya meninggal Jepang (Lie, 2012). Pada tahun 1970, bahkan terdapat kasus yang dibawa ke Pengadilan, karena adanya gugatan oleh warga Zainichi Korean kepada perusahaan Hitachi. Perusahaan Hitachi memecat (menggugurkan) rekrutmen pegawai barunya karena belakangan baru mengetahui identitasnya sebagai seorang imigran Korea. Kasus tersebut dimenangkan oleh pihak penggugat karena perusahaan tersebut dianggap melakukan diskriminasi terkait latar belakang pegawainya. Setelah tahun tersebut, mulai ada instansi pemerintah yang menghapuskan informasi terkait latar belakang negara dalam rekrutmen korporasi publik dan pemerintahan daerah (Kim, 2011). Faktor kebijakan dari pemerintah tersebut menjadi faktor yang sangat penting bagi keturunan Zainichi Korean untuk kedepannya bersaing adil dalam mendapatkan pekerjaan yang lebih layak dan memiliki prestise. Sehingga memungkinkan terjadinya mobilisasi sosial ekonomi ke kelas pekerjaan dengan rangking yang lebih tinggi sesuai dengan penilaian yang ada di masyarakat.

Analisis komparatif dilakukan terhadap kelompok Zainichi Korean bahwa mereka dilekati stereotip sebagai orang yang miskin dan tidak berpendidikan. Tetapi di penghujung abad ke dua puluh, para imigran Korea ini menikmati pendapatan yang ratarata cukup tinggi, dan tidak lagi menjadi kelompok yang tersisih karena tidak mapan secara ekonomi. Para imigran Korea ini di beberapa aspek masih mengalami diskriminasi, dalam lingkup nasional, baik itu mengenai persaingan bisnis ataupun rekrutmen dan promosi dalam bidang profesional. Sehingga, sebagian besar warga dari kelompok ini lebih memilih untuk berbisnis dan membangun usaha kelas mikro. Dalam memulai dan menjalankan bisnisnya, para imigran Korea ini mengoptimalkan relasi antara kelompoknya, sehingga mereka bisa berhasil dan mapan secara finansial. Di samping itu, banyak juga generasi muda para Zainichi Korea ini yang berupaya memperbaiki nasibnya dengan 
mengenyam pendidikan tinggi dengan serius. Sehingga, banyak juga generasi imigran Korea yang secara signifikan melampaui standarnya di masa lalu(Sugimoto, 2010).

Pada masa awal meledaknya gelombang budaya popular Korea (Korean Wave), drama Korea Winter Sonata memberikan pespektif baru terkait orang Korea. Stereotipe orang Korea sebagai orang yang kotor dan tidak dapat dipercaya meluntur secara signifikan (Kim, 2011). Popularitas Bae Yong Jun, tokoh pria utama dalam drama tersebut, di kalangan wanita paruh baya meroket drastis. Seketika itu banyak orang wanita Jepang yang menyukai drama tersebut menikmati berwisata ke Korea, ataupun mendaftar pada kursus bahasa Korea (Hanaki et al., 2007). Tetapi, perubahan persepsi ini masih terjadi secara sporadis, dan sebenarnya mereka yang menikmati drama ini memang memiliki sikap yang cenderung positif terkait pluralisme.

\section{Simpulan}

Pembahasan yang telah disampaikan menjelaskan bahwa terdapat proses perpindahan kelas sosial yang melewati lebih dari satu generasi. Mobilitas antar generasi Zainichi Korean di Jepang sebagian besar mampu menuju kelas yang ingin ditujunya, yaitu kelas sosial ekonomi yang lebih tinggi. Hal ini dapat dilihat dari mobilisasi keturunan Korea menuju kelas yang lebih di atas, dari kelas asal (class origin) orang tuanya. Terdapat faktor penghambat utama yaitu sikap diskriminatif sebagian orang Jepang kepada Zainichi Korea. Sikap tersebut berujung pada akses ke areal strategis seperti mendapat pekerjaan ataupun promosi pekerjaan yang lebih baik dipersulit. Misalnya, pada tahun 1990an, orang Korea kesulitan untuk mendapat pekerjaan, mereka hanya bisa bekerja sebagai pekerja harian. Akan tetapi, pada tahun 2000an, sebagian besar Zainichi Korea di Jepang mampu memiliki bisnis sendiri, bahkan 60-70\% restoran Yakiniku, tempat Pachinko, ataupun toko perhiasan dimiliki di daerah sentra imigran Korea. Penguatan di bidang ekonomi, menunjukkan bahwa terjadi mobilitas sosial ke atas pada Zainichi Korea yang tinggal di Jepang.

\section{Daftar Pustaka}

Arifin, M. H. (2017). Memahami Peran Pendidikan Tinggi terhadap Mobilitas Sosial di Indonesia. 22(2), 139-158. https://doi.org/10.7454/mjs.v22i2.7697

Brown, E. S. (2013). Racialization in a ' homogenous' society? The case of Buraku 
people in Japan. Asian Ethnicity, 14(1), 37-41.

https://doi.org/10.1080/14631369.2012.689556

Burgess, C. (2005). Jepang yang multikultur? Wacana dan mitos homogenitas [1] Chris Burgess Translated by Dipo Siahaan with the assistance of Susy Nataliwati, Muhamamad Surya and Danarto Suryo Yudo.

Creswell, J. W. (2014). Research Design Qualitative, Quantitative, and Mixed Method Approaches (4th ed.). SAGE Publication Ltd.

Damayanti, G. A. A. K. (2020). Problematika Pernikahan Generasi Milenial Terhadap Kasta di Bali. Satya Widya: Jurnal Studi Agama, 3(2).

Fanani, A. (2017). Identitas dan mobilitas sosial priyayi dalam novel para priyayi karya umar kayam. 12, 42-51.

Hanaki, T., Singhal, A., Han, M. W., Kim, D. K., \& Chitnis, K. (2007). Hanryu Sweeps East Asia; How Winter Sonata is Gripping Japan. The International Communication Gazette, 69(3), 281-294. https://doi.org/10.1177/1748048507076581

Harun, Y. (2016). LATAR BELAKANG PENGGUNAAN NAMA JEPANG ORANG KOREA. Seminar Hasil Penelitian Universitas Darma Persada.

Kim, B. (2011). "Blatant discrimination disappears, but... ": The politics of everyday exclusion in contemporary Japan. Asian Perspective, 35(2), 287-308. https://doi.org/10.1353/apr.2011.0008

Lie, J. (2004). Multietnic Japan. Havard University Press.

Lie, J. (2012). What is the K in K-pop? South Korean popular music, the culture industry, and National Identity. Korea Observer, 43(3), 339-363.

Nasiwan, \& Wahyuni, Y. S. (2016). Seri Teori-Teori Sosial Indonesia. UNY Press.

Pattinasarany, I. R. (2012). Mobilitas Sosial Vertikal Antar Generasi: Kajian Terhadap Masyarakat Kota di Provinsi Jawa Barat dan Jawa Timur. Universitas Indoenesia.

Soyomukti, N. (2014). Pengantar Sosiologi (kedua). AR-RUZZ Media.

Sugimoto, Y. (2010). An Introduction to Japanese Society (third). Cambridge University Press.

Suherman, E. D. (2004). Dinamika Masyarakat Jepang dari Masa Edo hingga Pascaperang Dunia II. Humaniora, 16(2), 201-210.

Wahyuningtyas, T. (2017). Pengaruh Tingkat Pendidikan dan Identitas Etnis Terhadap Peluang Mobilitas Sosial Intragenerasi Imigran Internasional Asal Cina. 
Univeritas Indonesia.

Wedayanti, N. P. L. (2021). Ujaran Kebencian Terhadap Zainichi Korean di Jepang (I. W. Pastika \& I. M. Puspani (eds.); pertama). Pustaka Larasan.

Wedayanti, N. P. L., \& Dewi, N. M. A. A. (2021). Wacana Rasisme Terhadap Golongan Minoritas di Jepang. Internatinal Seminar on Austronesian Language and Literature IX, 201-205.

Wirawan, I. (2015). TEORI-TEORI SOSIAL (keempat). Prenadamedia Group. 